\title{
Notes
}

\section{First Record of a Collapsed Dorsal Fin in a White-beaked Dolphin Lagenorhynchus albirostris, with a Gunshot Wound as a Possible Cause}

\author{
JEFF W. Higdon ${ }^{1}$ and DAVE SNOW ${ }^{2}$ \\ ${ }^{1} 45$ Pilgrim Avenue, Winnipeg, Manitoba R2M 0L3 Canada (corresponding author e-mail: jeff.higdon@gmail.com) \\ ${ }^{2}$ Wildland Tours Ltd., P.O. Box 383, 124 Water Street, St. John's, Newfoundland and Labrador A1C 5J9 Canada
}

Higdon, Jeff W., and Dave Snow. 2008. First record of a collapsed dorsal fin in a White-beaked Dolphin, Lagenorhynchus albirostris, with a gunshot wound as a possible cause. Canadian Field-Naturalist 122(3): 262-264.

Collapsed dorsal fins are rare in odontocete cetaceans, having been reported for only a few species. We present the first known case in a White-beaked Dolphin (Lagenorhynchus albirostris Gray, 1846), photographed off northern Newfoundland, Canada in September 2004. The animal also had a wound on the right side of its body, anterior to the dorsal fin, with an estimated average diameter of 20-37 mm. We consider this to be a gunshot wound, most likely a 12-gauge rifled slug. The dolphin appeared to be healthy and with no movement problems, and what was apparently the same animal was seen in the same area on several dates during 2005. There is a long history of hunting small cetaceans off the Labrador coast, and a gunshot wound is the most likely cause of the wound observed. The wound may have caused the dorsal fin to collapse, as noted in other dolphin species.

Key Words: White-beaked Dolphin, Lagenorhynchus albirostris, collapsed dorsal fin, gunshot wound, disfigurement, Newfoundland and Labrador.

The White-beaked Dolphin (Lagenorhynchus albirostris Gray, 1846) is common off Newfoundland and Labrador, in eastern Canada. On 9 September 2004 , one of us (DS) was leading a whale study group off St. Anthony in northern Newfoundland $\left(51^{\circ} 22^{\prime} \mathrm{N}\right.$; $\left.55^{\circ} 35^{\prime} \mathrm{W}\right)$ and encountered large numbers of Whitebeaked and Atlantic White-sided dolphins (Lagenorhynchus acutus) about $1.5 \mathrm{~km}$ offshore in approximately $60 \mathrm{~m}$ of water. The White-sided Dolphins were in a pod numbering thousands of individuals, with White-beaked Dolphins present in smaller groups. One White-beaked Dolphin (in a group of about 10 among a larger concentration of approximately 100) was observed with a completely collapsed dorsal fin, falling to the left side (Figure 1).

Collapsed or missing dorsal fins have been reported only rarely for any cetacean species (Baird and Gorgone 2005), and this observation represents, to our knowledge, the first report for this species. Closer observation of the photograph revealed what appeared to be a gunshot wound on the animal's right side, anterior to the dorsal fin (Figure 1). A gunshot wound would also be consistent with the small but regular harvest of dolphins that occurs off Labrador (Alling and Whitehead 1987; Lien et al. 2001). The dolphin appeared to be healthy with no locomotion problems, and the wound was not observed until the photographs were examined at a later time. An individual that appeared to be the same dolphin was also seen on at least three separate occasions by the tour boat operator during summer 2005, but was not photographed (P. Alcock, personal communication).

Measurements of White-beaked Dolphin dorsal fin base (Hai et al. 1996) were used to estimate the size of the wound, by comparing the ratio of dorsal fin base to the diameter of the wound in the photograph. The wound diameter was estimated using the widest points (i.e., the widest diameter given the photo angle, eastwest directions in Figure 1). Dorsal fin base is highly variable, ranging from 270-495 mm (Hai et al. 1996), resulting in a wide range $(29-53 \mathrm{~mm})$ for estimated wound diameter. Median dorsal fin base $(n=28)$ was $384 \mathrm{~mm}$, translating to an estimated wound diameter of $41 \mathrm{~mm}$.

Both White-beaked and White-sided dolphins (collectively known as "jumpers" or "squidhounds") are opportunistically hunted along the Labrador coast, primarily between August and October (Alling and Whitehead 1987; Lien et al. 2001). Contacts in Labrador have informed us that dolphins are hunted using either a .303 calibre rifle or a 12 gauge rifled slug, and that slugs typically create a deep hole which gets ragged over time. The bore diameter of a 12 gauge shotgun is $18.5 \mathrm{~mm}$ (0.729 inches). If wounds from rifled slugs do become larger and more ragged over time, then the estimated size of the wound would be comparable with this type of injury. A colleague has observed hunted dolphins from Labrador and suggested the wound 


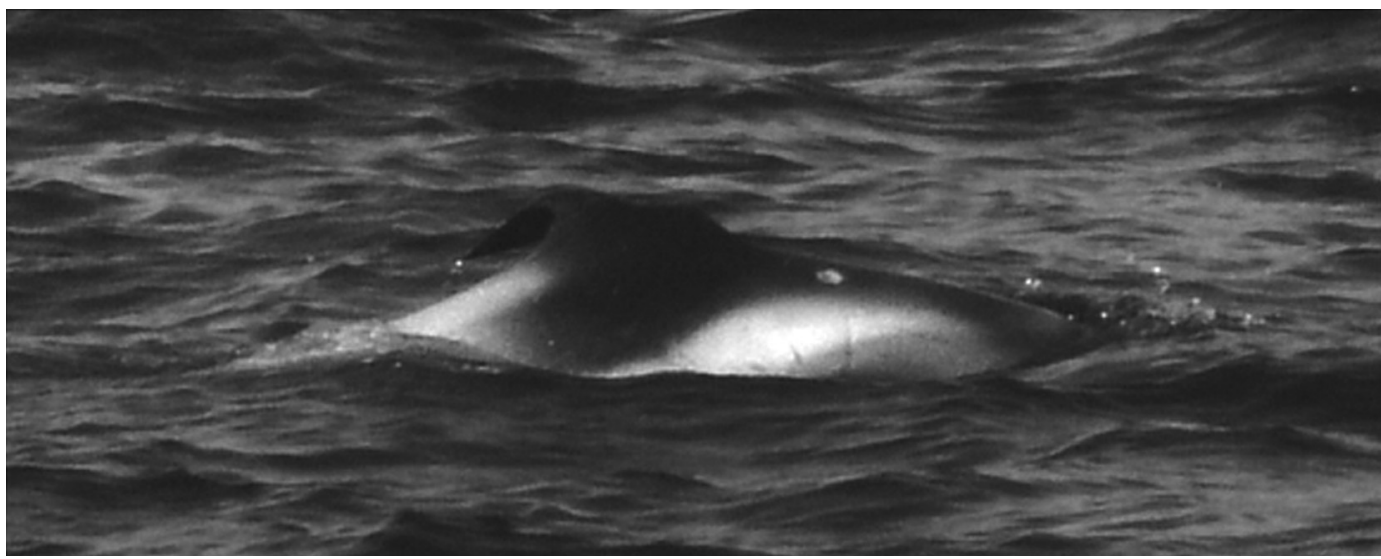

FIGURE 1. Photograph of a white-beaked dolphin (Lagenorhynchus albirostris Gray, 1846) with a collapsed dorsal fin taken 9 September 2004 off St. Anthony, Newfoundland (photograph by DS). Image clearly shows collapsed dorsal fin and the wound anterior to the dorsal fin.

shown here came from a rifled slug (M. Earle, personal communication).

There is always the possibility that the collapsed dorsal fin and apparent gunshot wound are not connected. However the wound may have caused infections in the cartilage, which can cause dorsal fin collapse $(\mathrm{H}$. Edwards, personal communication). Gunshots have been identified as a causal factor in collapsed dorsal fins in Killer Whales (Orcinus orca) (Bigg et al. 1987). Other known causes (reviewed by Baird and Gorgone 2005) include intra- and inter-specific interactions, fishing gear entanglement, boat strikes, scarring from tags, and deliberate notching for identification purposes. Dorsal fin collapse appears to be rare in odontocetes, with rates in well-studied populations generally ranging from zero to $<1 \%$ (Baird and Gorgone 2005). Guerrero-Ruiz et al. (2005) examined published catalogues of Killer Whales from Alaska to Mexico, and noted that only one out of $>1000$ resident whales and two of $>300$ transient whales had totally collapsed dorsal fins (all adult males).

Other possible causes of a circular wound include a fresh blubber biopsy dart wound or a Cookiecutter Shark (Isistius brasiliensis) bite. However, based on the location of the sighting and our knowledge of the local area, including current cetacean research being conducted, we believe the injury was caused by a gunshot. Biopsy darts usually make somewhat superficial wounds, and this wound appeared deeper. Cookiecutter Shark bite wounds have been observed on a number of cetacean species (Norris and Dohl 1980; Mead 1989; Debrot and Barros 1992; Gasparini and Sazima 1996). This shark is found worldwide in tropical and subtropical waters and will sometimes extend its range into higher latitudes in regions of warm currents (Jahn and Haedrich 1987; Munoz-Chapuli et al. 1998). However, it has not been found in the wellsampled Gulf Stream region (Jahn and Haedrich 1987) and this observation is considerably north of the known range. Cookiecutter Shark bites are typically $50-80 \mathrm{~mm}$ in diameter (Gasparini and Sazima 1996; Lucas and Hooker 2000), but the estimated diameter of the wound here was much smaller (maximum $53 \mathrm{~mm}$ ).

The dorsal fin is important to thermoregulation as it provides cooled blood to the female reproductive system (Rommel et al. 1993). The sex of this animal is unknown; but, if female, the collapsed dorsal fin could cause potential future reproduction problems. However, Baird and Gorgone (2005) observed two disfigured False Killer Whales (Pseudorca crassidens) (presumed adult females) accompanied by young calves, implying that at least some disfigured females are able to thermoregulate successfully and reproduce. The animal discussed here appeared perfectly healthy (other than the collapsed fin) and was likely the same animal seen again in 2005. There were no movement problems and it behaved no differently than other dolphins present.

\section{Acknowledgments}

The observation reported here was made during Wildland Tour's Northern Whale Study Expedition, from a vessel owned and operated by Paul Alcock in St. Anthony, Newfoundland and Labrador (Northland Discovery Tours). Helpful comments and suggestions were provided by M. Earle, H. Edwards, A. Gorgone, L. Hansen, P. Hasse and J. Lien. Previous drafts were improved by comments from S. H. Ferguson, Z. Z. Kuzyk, P. Richard, and two anonymous referees.

\section{Literature Cited}

Alling, A. K., and H. P. Whitehead. 1987. A preliminary study of the status of white-beaked dolphins Lagenorhynchus albirostris and other small cetaceans off the coast of Labrador Canada. Canadian Field-Naturalist 101: 131135. 
Baird, R. W., and A. M. Gorgone. 2005. False killer whale dorsal fin disfigurement as a possible indicator of longline fishery interactions in Hawaiian waters. Pacific Science 59: 593-601.

Bigg, M. A., G. M. Ellis, J. K. B. Ford, and K. C. Balcomb. 1987. Killer whales: a study of their identification, genealogy, and natural history in British Columbia and Washington State. Phantom Press, Nanaimo, British Columbia.

Debrot, A. O., and N. B. Barros. 1992. Notes on a Gervais' beaked whale, Mesoplodon europaeus, and a dwarf sperm whale, Kogia simus, stranded in Curacao, Netherlands Antilles. Marine Mammal Science 8: 172-178.

Gasparini, J. L., and I. Sazima. 1996. A stranded melonheaded whale, Peponocephala electra, in southeastern Brazil, with comments on wounds from the cookiecutter shark, Isistius brasiliensis. Marine Mammal Science 12: 308-312.

Guerrero-Ruiz, M., I. Garcia-Godos, and J. R. Urban. 2005. Photographic match of a killer whale (Orcinus orca) between Peruvian and Mexican waters. Aquatic Mammals 31: 438-441.

Hai, D.-J., J. Lien., and D. Nelson. 1996. A contribution to the biology of the White-beaked Dolphin, Lagenorhynchus albirostris, in waters off Newfoundland. Canadian FieldNaturalist 110: 278-287.
Jahn, A. E., and R. L. Haedrich. 1987. Notes on the pelagic squaloid shark Isistius brasilensis. Biological Oceanography 5: 297-309.

Lien, J., D. Nelson, and D.-J. Hai. 2001. Status of the Whitebeaked Dolphin, Lagenorhynchus albirostris, in Canada. Canadian Field-Naturalist 115: 118-126.

Lucas, Z. N., and S. K. Hooker. 2000. Cetacean strandings on Sable Island, Nova Scotia, 1970-1998. Canadian FieldNaturalist 114: 45-61.

Mead, J. G. 1989. Beaked whales of the genus Mesoplodon. Pages 349-430 in Handbook of Marine Mammals Volume 4. Edited by S. H. Ridgeway and R. Harrison. Academic Press, London.

Munoz-Chapuli, R., J. C. Rey Salgadsa, and J. M. de la Serna. 1998. Biogeography of Isistius brasiliensis in the north-eastern Atlantic, inferred from crater wounds on swordfish (Xiphias gladius). Journal of the Marine Biological Association of the United Kingdom 68: 315-321.

Norris, K. S., and T. P. Dohl. 1980. Behavior of the Hawaiian USA spinner dolphin Stenella longirostris. Fishery Bulletin 77: 821-850.

Rommel, S. A., D. A. Pabst, and W. A. McLellan. 1993. Functional morphology of the vascular plexuses associated with the cetacean uterus. Anatomical Record 237: 538546.

Received 12 September 2006

Accepted 12 June 2009 